Barker, P.F., Camerlenghi, A., Acton, G.D., and Ramsay, A.T.S. (Eds.)

Proceedings of the Ocean Drilling Program, Scientific Results Volume 178

\title{
9. DATA Report: A SeARCh for Deposits OF the LATE PLIOCENe IMPACT OF THE ELTANIN ASTEROID IN RISE SEDIMENTS FROM THE ANTARCTIC Peninsula, Site 1096'
}

Frank T. Kyte ${ }^{2}$

\begin{abstract}
Concentrations of Ir have been measured in 87 sediment samples from Ocean Drilling Program Site 1096 in search of evidence of fallout from the impact of the Eltanin asteroid, which occurred at $2.15 \mathrm{Ma}$, $\sim 1300 \mathrm{~km}$ northwest of the site. An additional six samples were measured from a unique sand layer and adjacent sediments that are dated at $\sim 1.6 \mathrm{Ma}$. These 93 sediment samples are all silts and muds that were deposited on a continental rise drift of the Antarctic Peninsula. No evidence of the Eltanin impact deposit was found in this study.

\section{INTRODUCTION}

One objective of the Ocean Drilling Program (ODP) Leg 178 expedition was to search for sediment deposits related to the late Pliocene impact of the Eltanin asteroid. This is a unique deposit in the known sedimentary record. It is the only known deposit recording the events surrounding the impact of a kilometer-sized asteroid into a deep $(5 \mathrm{~km})$ ocean basin. The exact point of impact is unknown, but it is believed to have occurred in the Bellingshausen Sea in a region $~ 1000 \mathrm{~km}$ west of Cape Horn $\left(58^{\circ} \mathrm{S}, 90^{\circ} \mathrm{W}\right)$. Details of the study of this impact are found in a series of five papers (Kyte et al., 1981, 1988; Kyte and Brownlee, 1985; Margolis et al., 1991; Gersonde et al., 1997). The impact ejecta deposits

${ }^{1}$ Kyte, F.T., 2001. Data report: A search for deposits of the late Pliocene impact of the Eltanin asteroid in rise sediments from the Antarctic Peninsula, Site 1096. In Barker, P.F., Camerlenghi, A., Acton, G.D., and Ramsay, A.T.S. (Eds.), Proc. ODP, Sci. Results, 178, 1-6 [Online]. Available from World Wide Web: <http://wwwodp.tamu.edu/publications/178_SR/ VOLUME/CHAPTERS/SR178_09.PDF>. [Cited YYYY-MM-DD]

${ }^{2}$ Center for Astrobiology, Institute of Geophysics and Planetary Physics, University of California, Los Angeles, Los Angeles CA 90095-1567, USA. kyte@igpp.ucla.edu

Initial receipt: 22 August 2000 Acceptance: 4 April 2001

Web publication: \#\# Month 2001 Ms 178SR-217
\end{abstract}


near ground zero contain millimeter- to centimeter-sized debris composed of Ir-rich impact melt and unmelted meteorites. About $500 \mathrm{~km}$ east of the impact region, at USNS Eltanin site E10-2, debris as large as $-1 \mathrm{~mm}$ was recovered (Kyte et al., 1988). These deposits provide a natural laboratory for studying processes related to the formation and preservation of Ir-rich meteoritic ejecta. The current estimate of the size of the projectile (Gersonde et al., 1997), from 1 to $4 \mathrm{~km}$ in diameter, is well within the range of asteroid sizes proposed to have global consequences (Chapman and Morrison, 1994). This impact must have generated large tsunamis throughout much of the Pacific basin and around much of the Southern Ocean.

Finding and characterizing the ejecta deposits at new sites would be an important next step in understanding the magnitude of this impact event. Nearly all of the data on this impact are restricted to five piston cores, all within a radius of $\sim 70 \mathrm{~km}$ (Gersonde et al., 1997) and quite near the suspected impact site. New data at sites with greater distances from the impact would provide better constraints on the size, and thus the energy, of the impact event. ODP Leg 178 researchers drilled shelf and rise sediments along the western side of the Antarctic Peninsula in an area $\sim 1300 \mathrm{~km}$ southeast of the Eltanin impact area and thus had the potential to recover deposits from this impact. In this paper, results of the attempt to find evidence of this deposit are described.

\section{SAMPLE SELECTION}

During the Leg 178 cruise, shipboard scientists actively searched for evidence of the impact of the Eltanin asteroid. This was primarily through an attempt to note unusual sediment deposits in cores from continental rise deposits, particularly in sediments of late Pliocene through early Pleistocene age. Gersonde et al. (1997) dated the impact at $2.15 \mathrm{Ma}$, just prior to the Reunion Event (Chron C2r.1n), or just before oxygen isotope Stage 82.

The only particularly unusual sediment deposit recovered at the rise sites was a massive, well-sorted sand bed that occurred at 112 meters beIow seafloor (mbsf) in Hole 1096B (Shipboard Scientific Party, 1999a). This bed was unusual in that it was unique within a partly turbiditic section of silts and muds. It was speculated that this might be from a massive flow triggered by a tsunami, possibly an impact event. Unfortunately, the 1.6-Ma age of this unit precluded the possibility that it might be related to the Eltanin impact event.

The only rise site at which the Reunion Event was tentatively identified was Site 1101 (Shipboard Scientific Party, 1999b), where it occurred at the base of lithostratigraphic Unit II at 142.7 mbsf. Unfortunately, the base of Unit II was defined by the last of a number of foraminiferbearing interglacial deposits and this particular layer was well calcified. During coring, $4 \mathrm{~m}$ of flow-in occurred below this layer and no sediments were recovered just below the Reunion Event.

During postcruise analysis of the record at Site 1096 (Shipboard Scientific Party, 1999a), the author noted a short magnetic reversal to normal polarity near the base of lithostratigraphic Unit II. At Site 1096, Unit II was similar to that at Site 1101 and its base was defined as the last foraminifer-bearing interglacial bed. The short reversal near the base of Unit II had not been interpreted by the Shipboard Scientific Party, but it appears to be a well-defined reversal that occurs across several samples with an onset at Sample 178-1096C-2H-1, 75-80 cm 
(169.25-169.30 mbsf), and a termination at Sample $2 \mathrm{H}-2,35-85 \mathrm{~cm}$ (167.35-167.85 m) (G. Acton, pers. comm., 1998). By comparison, the base of Unit II is at $173 \mathrm{mbsf}$.

Samples were taken from two levels at Site 1096. Six samples were taken from Hole 1096B near the unique sand deposit. These included the sand from the top of the bed and silts from the overlying sediments. If this bed formed as a result of an impact tsunami, it was assumed that meteoritic ejecta settling through the water column would be deposited on the top of the sediment flow, as has been noted at Cretaceous/Tertiary boundary sites with impact wave-triggered deposits along the Gulf of Mexico (e.g., Smit, 1999). Another 85 samples were initially selected from near the base of Unit II and below the short magnetic normal interval in sediments from Holes $1096 \mathrm{~B}$ and $1096 \mathrm{C}$. These samples ranged from Sample 178-1096B-19H-1, 50-51 cm (151.2 mbsf), to 24X-6, 16$17 \mathrm{~cm}(191.32 \mathrm{mbsf})$. Of these samples, 48 were closely spaced $(\sim 10-\mathrm{cm}$ intervals) from 168.5 to $174.38 \mathrm{mbsf}$, thus extending from the magnetic reversal to below the base of Unit II. All these samples were analyzed for Ir concentration in hopes of finding an anomaly indicative of impact ejecta.

\section{ANALYTICAL PROCEDURES}

Freeze-dried sediment samples, typically 0.5 to $1.0 \mathrm{~g}$, were pulverized in a high-purity alumina mortar. Powders weighing $100 \mathrm{mg}$ were sealed in quartz-glass tubes and irradiated at the University of Missouri Research Reactor Facility for $40 \mathrm{hr}$ at a neutron flux of $5 \times 10^{13} \mathrm{n} / \mathrm{cm}^{2} / \mathrm{s}$. Following irradiation, Ir was chemically purified using a procedure similar to that described by Kyte et al. (1993) and counted on intrinsic Ge detectors for up to $24 \mathrm{hr}$, beginning about 1 month following irradiation.

\section{RESULTS}

This initial survey found that only one sample had anomalous levels of Ir (Table T1). The other 90 samples had Ir levels ranging from 9 to 37 $\mathrm{pg} / \mathrm{g}$, average $=17 \mathrm{pg} / \mathrm{g}$. Such low concentrations are probably reasonable for rapidly accumulating terrigenous sediments. Sample 178$1096 \mathrm{C}-2 \mathrm{H}-4,50-51 \mathrm{~cm}(172.13 \mathrm{mbsf})$, was found to contain $88 \mathrm{pg} / \mathrm{g}$, an Ir concentration five times the background level. To test whether this might be a meteoritic signal, two additional samples were taken at 172.10 and $\mathbf{1 7 2 . 1 5} \mathrm{mbsf}$, closely bracketing the anomalous sample. These samples and another split of the sample from $172.13 \mathrm{mbsf}$ were irradiated and analyzed in a manner similar to the original batch. Unfortunately, the split of the anomalous sample from $172.13 \mathrm{mbsf}$ was spilled during chemical processing and the Ir value has not been replicated. The two adjacent samples were found to have normal Ir concentrations of $\sim 20 \mathrm{pg} / \mathrm{g}$.

As a final check of the sample with anomalous Ir at $172.13 \mathrm{mbsf}$, the remaining $3.2 \mathrm{~g}$ of material was wet sieved at 79 and $44 \mu \mathrm{m}$ and these fractions were examined microscopically. A similar procedure was applied to $2.9 \mathrm{~g}$ of sediment from a background sample from $172.28 \mathrm{mbsf}$. In both samples, the $>79-\mu \mathrm{m}$ fraction contained only a few rock and mineral grains that were probably mostly quartz. No vesicular melt particles or impact spherules typical of the Eltanin impact debris (Kyte and T1. Iridium concentrations, Site
1096, p. 6. 


\section{F.T. KYTE}

Data Report: Search for Eltanin Asteroid Impact Deposits

Brownlee, 1985; Margolis et al., 1991) were identified. The $>44-\mu \mathrm{m}$ fractions contained abundant felsic mineral grains (probably quartz and feldspars) and pyrite. Both samples were quite similar, and neither contained identifiable meteoritic impact debris. The normal Ir concentration in samples adjacent to the one at $172.13 \mathrm{mbsf}$ and the absence of particulate impact debris in that sample suggest that the Ir anomaly may have been spurious, likely caused by contamination or a stray cosmic spherule.

\section{CONCLUSION}

There is no strong evidence supporting the existence of Eltanin impact ejecta in sediments collected during ODP Leg 178.

\section{ACKNOWLEDGMENTS}

Samples were provided by the Ocean Drilling Program. This work was supported by JOI Grant G3397. The author thanks F. Asaro for a helpful review. 


\section{REFERENCES}

Chapman, C.R., and Morrison, D., 1994. Impacts on the Earth by asteroids and comets: assessing the hazard. Nature, 367:33-40.

Gersonde, R., Kyte, F.T., Bleil, U., Diekmann, B., Flores, J.A., Gohl, K., Grahl, G., Hagen, R., Kuhn, G., Sierro, F.J., Voelker, D., Abelmann, A., and Bostwick, J.A., 1997. Geological record and reconstruction of the late Pliocene impact of the Eltanin asteroid in the Southern Ocean. Nature, 390:357-363.

Kyte, F.T., and Brownlee, D.E., 1985. Unmelted meteoritic debris in the late Pliocene iridium anomaly: evidence for the ocean impact of a nonchondritic asteroid. Geochim. Cosmochim. Acta, 49:1095-1108.

Kyte, F.T., Heath, G.R., Leinen, M., and Zhou, L., 1993. Cenozoic sedimentation history of the central North Pacific: inferences from the elemental geochemistry of core LL44-GPC3. Geochim. Cosmochim. Acta, 57:1719-1740.

Kyte, F.T., Zhou, Z., and Wasson, J.T., 1981. High noble metal concentrations in a late Pliocene sediment. Nature, 292:417-420.

Kyte, F.T., Zhou, L., and Wasson, J.T., 1988. New evidence on the size and possible effects of a late Pliocene oceanic asteroid impact. Science, 24:63-65.

Margolis, S.V., Claeys, P.F., and Kyte, F.T., 1991. Microtektites, microkrystites and spinels from a late Pliocene asteroid impact in the Southern Ocean. Science, 251:1594-1597.

Shipboard Scientific Party, 1999a. Site 1096. In Barker, P.F., Camerlenghi, A., Acton, G.D., et al., Proc. ODP, Init. Repts., 178, 1-144 [CD-ROM]. Available from: Ocean Drilling Program, Texas A\&M University, College Station, TX 77845-9547, U.S.A.

, 1999b. Site 1101. In Barker, P.F., Camerlenghi, A., Acton, G.D., et al., Proc. ODP, Init. Repts., 178, 1-83 [CD-ROM]. Available from: Ocean Drilling Program, Texas A\&M University, College Station, TX 77845-9547, U.S.A.

Smit, J., 1999. The global stratigraphy of the Cretaceous-Tertiary boundary impact ejecta. Annu. Rev. Earth Planet. Sci., 27:75-113. 


\section{F.T. KYTE}

Data Report: Search for Eltanin Asteroid Impact Deposits

Table T1. Iridium concentrations in selected sediment samples, Site 1096.

\begin{tabular}{lll}
\hline $\begin{array}{c}\text { Core, section, } \\
\text { interval (cm) }\end{array}$ & $\begin{array}{c}\text { Depth } \\
(\mathrm{mbsf})\end{array}$ & $\begin{array}{c}\text { Ir } \\
\text { (pg/g) }\end{array}$ \\
\hline $178-1096 \mathrm{~B}-$ & & \\
$13 \mathrm{H}-2,115-116$ & 110.95 & 24 \\
$13 \mathrm{H}-2,125-126$ & 111.05 & 22 \\
$13 \mathrm{H}-2,130-131$ & 111.10 & 28 \\
$13 \mathrm{H}-2,135-136$ & 111.15 & 27 \\
$13 \mathrm{H}-2,140-141$ & 111.20 & 22 \\
$13 \mathrm{H}-2,149-150$ & 111.29 & 10 \\
$19 \mathrm{H}-1,50-51$ & 151.20 & 12 \\
$19 \mathrm{H}-3,80-81$ & 154.50 & 14 \\
$19 \mathrm{H}-5,57-58$ & 157.27 & 30 \\
$2 \mathrm{H}-1,77-78$ & 158.47 & 16 \\
$20 \mathrm{H}-3,46-47$ & 161.16 & 9 \\
$20 \mathrm{H}-6,44-45$ & 165.64 & 11 \\
$22 \mathrm{X}-1,11-12$ & 167.01 & 10 \\
$23 \mathrm{X}-1,78-79$ & 174.78 & 12 \\
$23 \mathrm{X}-2,78-79$ & 176.31 & 10 \\
$23 \mathrm{X}-3,78-79$ & 177.71 & 12 \\
$23 \mathrm{X}-4,78-79$ & 179.21 & 11 \\
$23 \mathrm{X}-5,57-58$ & 180.50 & 12 \\
$24 \mathrm{X}-1,17-18$ & 183.77 & 17 \\
$24 \mathrm{X}-3,75-76$ & 187.26 & 18 \\
$24 \mathrm{X}-6,31-32$ & 191.32 & 12 \\
$178-1096 \mathrm{C}-$ & & \\
$2 \mathrm{H}-1,114-115$ & 168.14 & 15 \\
$2 \mathrm{H}-1,133-134$ & 168.33 & 13 \\
$2 \mathrm{H}-2,24-25$ & 168.74 & 14 \\
$2 \mathrm{H}-2,35-36$ & 168.85 & 13 \\
$2 \mathrm{H}-2,45-46$ & 168.95 & 17 \\
$2 \mathrm{H}-2,53-54$ & 169.03 & 12 \\
$2 \mathrm{H}-2,65-66$ & 169.15 & 11 \\
$2 \mathrm{H}-2,75-76$ & 169.25 & 12 \\
$2 \mathrm{H}-2,79-80$ & 169.29 & 12 \\
$2 \mathrm{H}-2,85-86$ & 169.35 & 11 \\
$2 \mathrm{H}-2,95-96$ & 169.45 & 17 \\
$2 \mathrm{H}-2,105-106$ & 169.55 & 12 \\
$2 \mathrm{H}-2,117-118$ & 169.67 & 14 \\
$2 \mathrm{H}-2,125-126$ & 169.75 & 14 \\
$2 \mathrm{H}-2,135-136$ & 169.85 & 14 \\
$2 \mathrm{H}-2,145-146$ & 169.95 & 10 \\
$2 \mathrm{H}-3,5-6$ & 170.11 & 13 \\
$2 \mathrm{H}-3,12-13$ & 170.18 & 12 \\
$2 \mathrm{H}-3,15-16$ & 170.21 & 14 \\
$2 \mathrm{H}-3,25-26$ & 170.31 & 14 \\
$2 \mathrm{H}-3,35-36$ & 170.41 & 15 \\
$2 \mathrm{H}-3,45-46$ & 170.51 & 16 \\
$2 \mathrm{H}-3,54-55$ & 170.60 & 24 \\
$2 \mathrm{H}-3,55-56$ & 170.61 & 15 \\
$2 \mathrm{H}-3,65-66$ & 170.71 & 12 \\
& &
\end{tabular}

\begin{tabular}{|c|c|c|}
\hline $\begin{array}{l}\text { Core, section, } \\
\text { interval }(\mathrm{cm})\end{array}$ & $\begin{array}{l}\text { Depth } \\
\text { (mbsf) }\end{array}$ & $\begin{array}{c}\mathrm{Ir} \\
(\mathrm{pg} / \mathrm{g})\end{array}$ \\
\hline $2 \mathrm{H}-3,75-76$ & 170.81 & 15 \\
\hline $2 \mathrm{H}-3,85-86$ & 170.91 & 14 \\
\hline $2 \mathrm{H}-3,95-96$ & 171.01 & 16 \\
\hline $2 \mathrm{H}-3,105-106$ & 171.11 & 15 \\
\hline $2 \mathrm{H}-3,117-118$ & 171.23 & 13 \\
\hline $2 \mathrm{H}-3,125-126$ & 171.31 & 23 \\
\hline $2 \mathrm{H}-3,135-136$ & 171.41 & 15 \\
\hline $2 \mathrm{H}-3,145-146$ & 171.51 & 15 \\
\hline $2 \mathrm{H}-4,5-6$ & 171.68 & 13 \\
\hline $2 \mathrm{H}-4,11-12$ & 171.74 & 23 \\
\hline $2 \mathrm{H}-4,15-16$ & 171.78 & 13 \\
\hline $2 \mathrm{H}-4,25-26$ & 171.88 & 15 \\
\hline $2 \mathrm{H}-4,35-36$ & 171.98 & 16 \\
\hline $2 \mathrm{H}-4,45-46$ & 172.08 & 10 \\
\hline $2 \mathrm{H}-4,47-48$ & 172.10 & 19 \\
\hline $2 \mathrm{H}-4,50-51$. & 172.13 & 88 \\
\hline $2 \mathrm{H}-4,52.53$ & 172.15 & 23 \\
\hline $2 \mathrm{H}-4,55-56$ & 172.18 & 13 \\
\hline $2 \mathrm{H}-4,65-66$ & 172.28 & 13 \\
\hline $2 \mathrm{H}-4,75-76$ & 172.38 & 16 \\
\hline $2 H-4,86-87$ & 172.49 & 15 \\
\hline $2 \mathrm{H}-4,95-96$ & 172.58 & 13 \\
\hline $2 \mathrm{H}-4,105-106$ & 172.68 & 16 \\
\hline $2 \mathrm{H}-4,115-116$ & 172.78 & 14 \\
\hline $2 \mathrm{H}-4,117-118$ & 172.80 & 15 \\
\hline $2 \mathrm{H}-4,125-126$ & 172.88 & 17 \\
\hline $2 \mathrm{H}-4,135-136$ & 172.98 & 16 \\
\hline $2 \mathrm{H}-4,145-146$ & 173.08 & 13 \\
\hline $2 H-5,5-6$ & 173.26 & 16 \\
\hline $2 \mathrm{H}-5,11-12$ & 173.32 & 18 \\
\hline $2 \mathrm{H}-5,15-16$ & 173.36 & 19 \\
\hline $2 \mathrm{H}-5,25-26$ & 173.46 & 21 \\
\hline $2 \mathrm{H}-5,35-36$ & 173.56 & 20 \\
\hline $2 \mathrm{H}-5,45-46$ & 173.66 & 22 \\
\hline $2 \mathrm{H}-5,53-54$ & 173.74 & 35 \\
\hline $2 \mathrm{H}-5,65-66$ & 173.86 & 31 \\
\hline $2 \mathrm{H}-5,75-76$ & 173.96 & 39 \\
\hline $2 \mathrm{H}-5,85-86$ & 174.06 & 31 \\
\hline $2 \mathrm{H}-5,86-87$ & 174.07 & 28 \\
\hline $2 \mathrm{H}-5,95-96$ & 174.16 & 36 \\
\hline $2 \mathrm{H}-5,105-106$ & 174.26 & 20 \\
\hline $2 \mathrm{H} .5,117.118$ & 174.38 & 15 \\
\hline $2 \mathrm{H}-6,11-12$ & 174.87 & 37 \\
\hline $2 \mathrm{H}-6,54-55$ & 175.30 & 13 \\
\hline $2 \mathrm{H}-6,87-88$ & 175.63 & 19 \\
\hline $2 H-6,117-118$ & 175.93 & 12 \\
\hline $2 \mathrm{H}-7,16-17$ & 176.42 & 16 \\
\hline
\end{tabular}

